\title{
Effect of prostaglandin on early surgical mortality in obstructive lesions of the systemic circulation
}

\author{
FRANCO LEONI, * JAMES C HUHTA, JOHN DOUGLAS, ROXANNE MACKAY, \\ MARC R DE LEVAL, FERGUS J MACARTNEY, JAROSLAV STARK
}

From the Thoracic Unit, The Hospital for Sick Children, London

SUMMARY To examine the effect of preoperative prostaglandin infusion on surgical mortality the records of all patients aged $\leqslant 28$ days operated between January 1979 and December 1981 for obstructive lesions of the systemic circulation were reviewed. Forty patients had coarctation of the aorta, five interrupted aortic arch, and seven critical aortic stenosis. Fourteen patients received intravenous prostaglandin before operation. Among preoperative variables low cardiac output was identified as a possible risk factor for hospital death, whereas the presence of a raised blood urea concentration was possibly significantly associated with hospital mortality only in patients not treated with prostaglandin. The preoperative administration of prostaglandin had a strongly favourable influence: 11 out of $38(29.0 \%)$ patients who did not receive prostaglandin died compared with none of 14 treated with prostaglandin. The two groups were otherwise comparable with respect to the incidence of coagulopathy, urgency of operation, associated anomalies, and other medical treatment. Mean age at operation was younger and mean admission blood urea concentration higher in the group treated with prostaglandin, whereas the incidence of preoperative low cardiac output was probably higher.

It is concluded that short term preoperative infusion of prostaglandin is associated with a significant reduction in early surgical mortality in this high risk group of infants.

Congenital malformations that obstruct the systemic circulation often present with low cardiac output and severe heart failure during the first weeks of life. Closure of the ductus arteriosus probably plays an important role in their natural history, and the maintenance of ductal patency by prostaglandin infusion has been reported to improve the clinical condition of some infants with coarctation of the aorta, interrupted aortic arch, and critical aortic stenosis. ${ }^{1-4}$

Although early surgical relief of the obstruction is mandatory, this is associated with a significant mortality. To determine if preoperative prostaglandin infusion might decrease operative mortality, we reviewed our preliminary experience with its use in the management of critically ill infants with obstructive lesions of the systemic circulation.

Requests for reprints to Mr J Stark, FRCS, Thoracic Unit, The Hospital for Sick Children, Great Ormond Street, London WCIN 3JH.

^Present addresses: Dr F Leoni, Institute Gaslini, Genova, Italy; Dr J C Huhta, Texas Children's Hospital, Houston, Texas; Dr R MacKay, Royal Liverpool Children's Hospital, Liverpool.

Accepted for publication 2 August 1984

\section{Patients and methods}

Between January 1979 (the first year in which prostaglandin was used in our institution for these conditions) and December 1981, 54 patients aged $\leqslant 28$ days were identified as having coarctation of the aorta, interrupted aortic arch, or critical aortic stenosis at this hospital. Sixteen of these patients received an intravenous infusion of prostaglandin $E_{1}$. Two were excluded from this study: an 8 day old infant with isolated coarctation died of acute haemorrhage after institution of peritoneal dialysis before operation and a 2 day old infant with mild coarctation died during attempted valvotomy for critical pulmonary stenosis. None of the patients who did not receive prostaglandin died from causes unrelated to left heart obstruction. Patients with hypoplastic left heart syndrome were not treated medically or surgically during this period. The 52 patients in this study ranged in age from 1 to 28 days (mean 10.4 days) at the time of operation.

Tables 1 and 2 summarise the anatomical and clinical characterisation of patients who did (group 1) and 
Table 1 Obstructive lesions of the systemic circulation in 14 patients treated with (group 1) and 38 not treated with (group 2) prostaglandin before operation

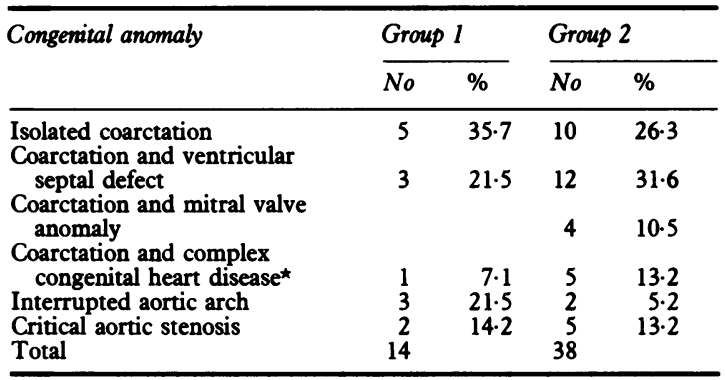

*Including two patients with double outlet right ventricle, two with univentricular heart, one with transposition of the great arteries, and one with transposition of the great arteries and ventricular septal defect.

did not (group 2) receive prostaglandin. Renal failure was considered to be present if the blood urea concentration exceeded $7 \mathrm{mmol} / \mathrm{l}$. Preoperative dialysis was performed for the indications previously described. 5 Low cardiac output was defined as the need for positive inotropic support to maintain a systolic blood pressure above $50 \mathrm{~mm} \mathrm{Hg}$ in combination with clinical signs of poor peripheral perfusion. Many patients also had severe metabolic acidosis, the mean (SD) $\mathrm{pH}$ in group 1 being $7 \cdot 22(0.23)$ and in group 2 $7.31(0.14)$ with a base deficit of $11.9(8.7)$ and $6.6(8.0)$ respectively.

If the patient's prothrombin time or partial thromboplastin time was greater than twice the control value coagulopathy was considered to be present; most of these patients also had reduced platelet counts, hypofibrinogenaemia, and overt clinical bleeding.

Any operation performed within 24 hours of admission or necessitated by sudden clinical deterioration was considered to be an emergency procedure. The timing of surgery to some extent, however, also reflected other factors, such as the availability of operating facilities and the time spent correcting clotting defects. With growing experience in the use of cross sectional echocardiography an increasing number of patients underwent operation without preliminary diagnostic cardiac catheterisation or angiography. ${ }^{6}$ Mean age at the time of surgery was 7.6 days (range 2-15 days) among patients who received prostaglandin and 11.5 days (range 1-26 days) among those who did not $(\mathrm{p}<0.05)$. Before January 1981, prostaglandin infusion was reserved for those infants presenting with renal failure, which had been shown to be a risk factor for operative death from repair of coarctation. ${ }^{7}$ Subsequently, the indications were widened to include all patients with absence of lower extremity arterial pulses together with any combination of renal failure, low cardiac output, coagulopathy, or severe metabolic acidosis. Prostaglandin $\mathrm{E}_{1}$ was administered by continuous infusion into an upper extremity or internal jugular vein at a dose of $0.02-0.1 \mu \mathrm{g} / \mathrm{kg} / \mathrm{min}$. Of the 14 patients in group 1, preoperative prostaglandin was infused for 4-10 hours in four, 10-24 hours in four, and longer than 24 hours in three. The three remaining patients were receiving prostaglandin treatment on admission to our unit and underwent operation between four and 10 hours after transfer.

Other supportive treatment included: (a) digoxin, dopamine $(3-6 \mu \mathrm{g} / \mathrm{kg} / \mathrm{min})$ in patients with low cardiac output; (b) correction of acidosis with sodium bicarbonate; $(c)$ ventilation as required to maintain adequate blood gases, and $(d)$ diuretics for oliguria.

Late follow up was obtained from outpatient or subsequent inpatient records, all patients having been followed to the time of death or to 1 January 1982.

\section{STATISTICAL ANALYSIS}

Data were analysed at the University of London Computing Centre using unpaired $t$ tests for univariate comparison of the means of continuous variables between groups and Fisher's exact test for $2 \times 2$ con-

Table 2 Preoperative status of patients with obstructive lesions of the systemic circulation treated with (group 1) and not treated with (group 2) prostaglandin

\begin{tabular}{|c|c|c|c|}
\hline & Group 1 & Statistical significance & Group 2 \\
\hline $\begin{array}{l}\text { No (\%) of patients with: } \\
\text { Low cardiac output } \\
\text { Renal failure } \\
\text { Coagulopathy } \\
\text { Emergency operation } \\
\text { Mean (SD) age at operation (days) } \\
\text { Mean (SD) arterial pH } \\
\text { Mean (SD) arterial base deficit } \\
\text { Mean (SD) blood urea concentration (mmol/l) }\end{array}$ & $\begin{array}{l}8(57) \\
9(64 \cdot 4) \\
4(28 \cdot 5) \\
8(57 \cdot 1) \\
7 \cdot 6(4 \cdot 0) \\
7 \cdot 22(0 \cdot 23) \\
-11 \cdot 9(8 \cdot 7) \\
9 \cdot 4(4 \cdot 6)\end{array}$ & $\begin{array}{l}\mathrm{p}=0.07 \\
\mathrm{p}<0.05 \\
\mathrm{NS} \\
\mathrm{NS} \\
\mathrm{p}<0.05 \\
\mathrm{NS} \\
\mathrm{p}<0.05 \\
\mathrm{p}<0.01\end{array}$ & $\begin{array}{l}13(34 \cdot 2) \\
8(21) \\
7(18 \cdot 4) \\
21(55 \cdot 3) \\
11 \cdot 5(6 \cdot 4) \\
7 \cdot 31(0 \cdot 14) \\
-6 \cdot 6(8 \cdot 0) \\
6 \cdot 1(3 \cdot 8)\end{array}$ \\
\hline
\end{tabular}

NS, not significant.

Conversion: SI to traditional units-urea: $1 \mathrm{mmol} \approx 6 \mathrm{mg}$. 
Table 3 Early mortality in 11 patients undergoing surgery without preoperative prostaglandin infusion

\begin{tabular}{|c|c|c|c|c|}
\hline $\begin{array}{l}\text { Age } \\
\text { (days) }\end{array}$ & Diagnosis & Operation & $\begin{array}{l}\text { Time of death } \\
\text { (postoperatively) }\end{array}$ & Cause of death \\
\hline $\begin{array}{r}5 \\
3 \\
13 \\
26\end{array}$ & $\begin{array}{l}\text { Coarctation } \\
\text { Coarctation and VSD } \\
\text { Coarctation and VSD } \\
\text { Coarctation and multiple VSDs }\end{array}$ & $\begin{array}{l}\text { Resection } \\
\text { Subclavian flap angioplasty } \\
\text { Subclavian flap angioplasty } \\
\text { Subclavian flap angioplasty, } \\
\text { pulmonary artery band }\end{array}$ & $\begin{array}{l}4 \text { days } \\
5 \text { hours } \\
2 \text { hours } \\
2 \text { hours }\end{array}$ & $\begin{array}{l}\text { Renal failure, acidosis } \\
\text { Low cardiac output } \\
\text { Low cardiac output } \\
\text { Low cardiac outputt }\end{array}$ \\
\hline $\begin{array}{r}12 \\
19 \\
1 \\
7\end{array}$ & $\begin{array}{l}\text { Coarctation, complex CHD } \\
\text { Coarctation, complex CHD } \\
\text { Coarctation, complex CHD } \\
\text { Aortic stenosis }\end{array}$ & $\begin{array}{l}\text { Subclavian flap angioplasty } \\
\text { Subclavian flap angioplasty } \\
\text { Subclavian flap angioplasty } \\
\text { Valvotomy (cardiopulmonary } \\
\text { bypass) }\end{array}$ & $\begin{array}{l}5 \text { days } \\
4 \text { days } \\
5 \text { days } \\
\text { At operation }\end{array}$ & $\begin{array}{l}\text { Low cardiac output } \\
\text { Sudden death, no necropsy performed } \\
\text { Low cardiac output } \\
\text { Low cardiac output }{ }^{\star}\end{array}$ \\
\hline $\begin{array}{l}9 \\
1 \\
7\end{array}$ & $\begin{array}{l}\text { Aortic stenosis } \\
\text { Interrupted aortic arch } \\
\text { Interrupted aortic arch }\end{array}$ & $\begin{array}{l}\text { Valvotomy (inflow occlusion) } \\
\text { No procedure } \\
\text { Anastomosis, pulmonary } \\
\text { artery band }\end{array}$ & $\begin{array}{l}2 \text { hours } \\
\text { At operation } \\
2 \text { days }\end{array}$ & $\begin{array}{l}\text { Low cardiac output, renal failure } \\
\text { Low cardiac output } \\
\text { Low cardiac output }\end{array}$ \\
\hline
\end{tabular}

^Intracranial haemorrhage.

† Mitral atresia found at postmortem examination.

CHD, congenital heart disease; VSD, ventricular septal defect.

tingency tables. In both of the above, two tailed tests were used. Multivariate assessment of risk factors was carried out where possible using stepwise logistic regression.

\section{SURGICAL REPAIR}

Forty patients with coarctation of the aorta underwent repair; 37 by subclavian flap angioplasty, two by patch angioplasty, and one by end to end anastomosis. The pulmonary artery was banded in five patients. Two had patch angioplasty of the distal aortic arch, and one a reverse subclavian flap. Three of the five patients with interrupted aortic arch underwent palliative treatment by insertion of a prosthetic conduit between the main pulmonary artery and descending aorta, ligation of the persistent ductus arteriosus, and pulmonary artery banding distal to the conduit. The interruption was repaired by end to end anastomosis between the left subclavian artery and the descending aorta in one patient, who also had banding of the pulmonary artery. The final patient suffered irreversible cardiac arrest during thoracotomy, and no therapeutic operative procedure was accomplished. Transaortic valvotomy was performed in each of the seven patients with critical aortic stenosis, five under normothermic inflow occlusion and two during cardiopulmonary bypass.

\section{Results}

Preoperatively, clinical improvement was seen in eight of the 14 patients who received prostaglandin

Table 4 Late mortality in patients treated with prostaglandin (group 1) and not treated (group 2)

\begin{tabular}{|c|c|c|c|c|}
\hline $\begin{array}{l}\text { Age at } \\
\text { operation } \\
\text { (days) }\end{array}$ & Diagnosis & Operation & $\begin{array}{l}\text { Interval to } \\
\text { death after } \\
\text { operation } \\
\text { (months) }\end{array}$ & Cause of death \\
\hline 8 & Coarctation, complex CHD & $\begin{array}{l}\text { Group } 1 \\
\text { Reverse subclavian flap angioplasty } \\
\text { for correction of hypoplastic arch, } \\
\text { patch angioplasty of coarctation; } \\
\text { pulmonary artery banding }\end{array}$ & $21 / 2$ & Cardiac failure, infection \\
\hline 1 & Interrupted aortic arch & $\begin{array}{l}\text { Main pulmonary artery to descending } \\
\text { aorta conduit }\end{array}$ & 2 & $\begin{array}{l}\text { Respiratory failure, } \\
\text { bronchopulmonary dysplasia }\end{array}$ \\
\hline 8 & Interrupted aortic arch & $\begin{array}{l}\text { Main pulmonary artery to descending } \\
\text { aorta conduit }\end{array}$ & 1 & -Renal failure, cortical necrosis \\
\hline 2 & Aortic stenosis & Valvotomy & 1 & Cardiac and respiratory failure \\
\hline $\begin{array}{r}16 \\
8\end{array}$ & $\begin{array}{l}\text { Coarctation } \\
\text { Coarctation and VSD, } \\
\text { hypoplastic left ventricle } \\
\text { and mitral valve }\end{array}$ & $\begin{array}{l}\text { Subclavian flap, angioplasty } \\
\text { Subclavian flap, angioplasty }\end{array}$ & $10^{1 / 2}$ & $\begin{array}{l}\text { Sudden death, no necropsy performed } \\
\text { Cardiac failure }\end{array}$ \\
\hline
\end{tabular}

CHD, congenital heart disease; VSD, ventricular septal defect. 
infusion. Lower extremity pulses returned to normal volume in three, and one of the eight patients with low cardiac output showed improved peripheral perfusion. The plasma urea concentration fell in five of eight patients in renal failure, and metabolic acidosis decreased in four out of 13. Of the patients showing clinical improvement with prostaglandin infusion, five underwent elective surgery within 48 hours of the onset of infusion, whereas three underwent emergency operation.

Six patients showed no improvement after at least four hours of prostaglandin infusion, and operation was undertaken as an emergency in five of these. In the sixth patient, operation was delayed 24 hours to obtain benefit from peritoneal dialysis.

There were no deaths within seven days of the surgical procedure among the 14 patients treated preoperatively with prostaglandin. By contrast, there were 11 deaths in the first postoperative week in the group of 38 patients who did not receive prostaglan$\operatorname{din}(29.0 \%)(p=0.04)$. These all occurred at operation or in the immediate postoperative period (Table 3 ). Four late deaths (beyond 28 days) occurred in the prostaglandin treated group $1(28.5 \%)$, whereas there were three late deaths among the 27 survivors in the group without prostaglandin (group 2) $(11 \cdot 1 \%$ ) as summarised in Table 4. Two of the four patients who died late were among those who had shown preoperative improvement with prostaglandin. Seven day mortality was seven out of $34(20.6 \%)$ among patients who had undergone preoperative cardiac catheterisation, and four out of $18(22 \cdot 2 \%)$ among those who had not. This difference is not statistically significant. In the group as a whole, no risk factor apart from prostaglandin treatment was statistically significant by logistic regression. In the non-prostaglandin group there was a possible association (logistic $p=0.097$ ) between blood urea concentration on admission and death within seven days of operation.

\section{Discussion}

Prostaglandin $E_{1}$ and $E_{2}$ induce relaxation of ductal tissue in increased as well as low oxygen environments ${ }^{8-10}$ and may thereby provide a means of control of ductal patency. In cyanotic congenital heart disease with decreased pulmonary blood flow and ductus dependent pulmonary circulation, prostaglandin affords excellent temporary palliation. ${ }^{11^{-16}}$ More recently, prostaglandin has been used for aortic arch anomalies and coarctation, where part of the systemic circulation may depend on patency of the ductus arteriosus. ${ }^{1-4} 17$ The aim here is to prevent or alleviate the consequences of ductal closure such as low cardiac output, renal failure, and metabolic acidosis. This study suggests that the benefits of prostaglandin infusion are sufficient in this regard to justify delayed surgical intervention in some patients, thereby significantly reducing operative mortality.

The overall mechanism by which prostaglandin affords haemodynamic improvement in patients with obstructive lesions of the systemic circulation is probably complex and incompletely understood. In neonates with interrupted aortic arch, it has been shown to reduce the pressure gradient between main pulmonary artery and descending aorta, while in those with aortic coarctation it lowers the gradient between the ascending and descending aorta. ${ }^{3}$ This may reflect relaxation of ductal tissue present inside the aortic lumen ${ }^{18}$ or opening of the aortic end of the ductus. ${ }^{19}$ In addition, reduction of systemic resistance may benefit patients with isolated simple coarctation, where left ventricular failure has been shown to be related to afterload.20 Venting the right heart and pulmonary circulation towards the lower segment may help to correct fluid overload and acidosis indirectly by increasing renal blood flow.

When the aortic coarctation is associated with a ventricular septal defect, volume overload of the left ventricle, pressure overload of the right ventricle, and pulmonary hypertension occur. Prostaglandin may reduce the left to right shunt at ventricular level in these patients by decreasing systemic afterload, or it may possibly reduce the pressure overload of the right ventricle, again by venting the pulmonary circulation across the ductus. Nevertheless, pulmonary artery pressure does not fall in this condition. ${ }^{21}$

In this series, prostaglandin infusion alone resulted in clinical improvement in three patients. When combined with positive inotropic support, there was improvement in an additional five. Six patients, however, showed no changes in their clinical conditions and accordingly underwent emergency operation. In that operative mortality was reduced, even these patients may have had some haemodynamic benefit from the infusion of prostaglandin.

Several factors may have been responsible for a lack of clinical response; in one patient a haematoma of the ductus arteriosus was found at the time of operation and almost certainly caused mechanical occlusion of the ductus. In another 2 week old infant who presented with low cardiac output and severe renal failure, ductal patency may not have been sufficient in itself to reverse established low cardiac output. Prostaglandin had been started at the referring hospital and the ductus was widely patent at operation, although no clinical improvement was observed. The observation that patients with aortic obstruction require a longer period of prostaglandin infusion than infants with cyanotic congenital heart disease to achieve maximal clinical response ${ }^{21}$ suggests that improved myocardial function may be a prerequisite 
for clinical improvement in these patients. The most encouraging observation in this study was a significant reduction in operative mortality among the patients who received prostaglandin. Although patients who received prostaglandin were at least as ill preoperatively, as shown by the higher incidence of low cardiac output and renal failure, all survived the operative procedure. These indices of system failure indicate clearly that the younger age of the prostaglandin treated group reflected more serious degrees of cardiac abnormality. It is not possible to argue that the better results in the prostaglandin treated group were due to earlier referral since if this were true they should have had a lower not a higher preoperative incidence of low cardiac output and renal failure.

In both groups of patients late mortality reflected associated cardiac anomalies. As expected, mortality was not affected by prostaglandin and in no case could be attributed to residual aortic obstruction. Based on this limited experience, preoperative infusion of prostaglandin would appear to benefit patients with obstructive lesions of the systemic circulation who have low cardiac output. At present, it is not possible to decide exactly which criteria should be used to assess a patient's response or for how long prostaglandin should be given before operation in either those patients showing improvement or those who fail to respond. Nevertheless, even among patients who showed no detectable clinical improvement the operative mortality was reduced. Accordingly, our present policy is to use prostaglandin infusion in all infants with symptomatic obstructive lesions of the systemic circulation, while hoping that future analysis will clarify the indications particularly in the treatment of critical aortic stenosis. Here the mechanism of any beneficial effect is not as obvious as in the case of interrupted aortic arch, for example. All that can be said at present is that the results of this study are the same whether patients with critical aortic stenosis are excluded or included and that mortality was lower in those patients with aortic stenosis who were treated with prostaglandin, though the numbers are too small to give statistically significant results.

It is generally believed that preoperative cardiac catheterisation and angiocardiography are essential to the management of this group of patients. If this were so failure to perform cardiac catheterisation in these patients should have constituted a risk factor, whereas the seven day mortality was not significantly different in patients who did and did not undergo preoperative catheterisation. Since preoperative catheterisation itself constitutes a significant risk to these patients ${ }^{22}$ our results lead us to question the necessity for cardiac catheterisation when all aspects of non-invasive investigation, including clinical assessment, chest radiography, electrocardiography, and cross sectional echocardiography, are typical for the condition suspected. 6

JCH was a British Heart Foundation Overseas fellow, FJM is supported by the Vandervell and British Heart Foundations, and JD is supported by the British Heart Foundation.

\section{References}

1 Radford DJ, Bloom KR, Coceani F, Fariello R, Olley PM. Prostaglandin E1 for interrupted aortic arch in the neonate [Letter]. Lancet 1976; ii: 95.

2 Lang P, Freed MD, Rosenthal A, Castenada AR, Nadas AS. The use of prostaglandin El in an infant with interruption of the aortic arch. $\mathcal{F}$ Pediatr 1977; 91: 805-7.

3 Heymann MA, Berman W Jr, Rudolph AM, Whitman V. Dilatation of the ductus arteriosus by prostaglandin E1 in aortic arch abnormalities. Circulation 1979; 59: $169-73$.

4 Zahka KG, Roland JMA, Cutilletta AF, Gardner TJ, Donahoo JS, Kidd L. Management of aortic arch interruption with prostaglandin $\mathrm{E} 1$ infusion and microporous expanded polytetrafluoroethylene grafts. Am $\mathcal{F}$ Cardiol 1980; 46: 1001-5.

5 Rigden SPA, Barratt TM, Dillon MJ, de Leval M, Stark J. Acute renal failure complicating cardiopulmonary bypass surgery. Arch Dis Child 1982; 57: 425-30.

6 Stark J, Smallhorn J, Huhta J, et al. Surgery for congenital heart defects diagnosed with cross-sectional echocardiography. Circulation 1983; 68 (suppl II): 129-38.

7 Leanage R, Taylor JFN, de Leval MR, Stark J, Macartney FJ. Surgical management of coarctaction of aorta with ventricular septal defect. Multivariate analysis. $\mathrm{Br}$ Heart $f$ 1981; 46: 269-77.

8 Coceani F, Olley PM. The response of the ductus arteriosus to prostaglandins. Can $\mathcal{F}$ Physiol Pharmacol 1973; 51: 220-5.

9 Sharpe GL, Larsson KS. Studies on closure of the ductus arteriosus. X. In vivo effect of prostaglandin. Prostaglandins 1975; 9: 703-19.

10 Clyman RI, Heymann MA, Rudolph AM. Ductus arteriosus responses to prostaglandins E1 at high and low oxygen concentrations. Prostaglandins 1977; 13: 219-23.

11 Elliott RB, Starling MB, Neutze JM. Medical manipulation of the ductus arteriosus. Lancet 1975; i: 140-2.

12 Olley PM, Coceani F, Bodach E. E-type prostaglandins: a new emergency therapy for certain cyanotic congenital heart malformations. Circulation 1976; 53: 728-31.

13 Neutze JM, Starling MB, Elliott RB, Barrat-Boyes BG. Palliation of cyanotic congenital heart disease in infancy with E-type prostaglandins. Circulation 1977; 55: 23841.

14 Browdie DA, Norberg W, Agnew R, Altenberg B, Ignacio R, Hamilton C. The use of prostaglandin El and Blalock-Taussig shunt in neonates with cyanotic congenital heart disease. Ann Thorac Surg 1979; 27: 508-13.

15 Silove ED, Coe JY, Shiu MF, et al. Oral prostaglandin E2 in ductus-dependent pulmonary circulation. Circulation 1981; 63: 682-8.

16 Donahoo JS, Roland JM, Kan J, Gardner TJ, Kidd 
BSL. Prostaglandin El as an adjunet to emergency cardiac operation in neonates. I Thorac Cardiovasc Surg 1981; 81: 227-31.

17 Graham TP, Atwood GF, Boucek RJ. Use of prostaglandin El for emergency palliation of symptomatic coarctation of the aorta. Cathet Cardiovasc Diagn 1978; 4: 97102.

18 Ho SY, Anderson RH. Coarctation, tubular hypoplasia, and the ductus arteriosus. Histological study of 35 specimens. Br Heart f 1979; 41: 268-74.

19 Rudolph AM, Heymann MA, Spitznas U. Hemodynamic considerations in the development of nar- rowing of the aorta. Am $\mathcal{F}$ Cardiol 1972; 30: 514-25.

20 Graham TP Jr, Atwood GF, Boerth RC, Boucek RJ Jr, Smith CW. Right and left heart size and function in infants with symptomatic coarctation. Circulation 1977; 56: 641-7.

21 Freed MD, Heymann MA, Lewis AB, Roehl SL, Kensey RC. Prostaglandin E1 in infants with ductus arteriosus-dependent congenital heart disease. Circulation 1981; 64: 899-905.

22 Fyler DC, Buckley LP, Hellenbrand WE, et al. Report of the New England Regional Infant Cardiac Program. Pediatrics 1980; 65 (suppl): 375-461. 